\title{
Introduction
}

\section{Xeno-Racism and International Migration}

\author{
R. Cheran
}

\section{Introduction}

$\mathrm{T}$ This special issue of Refuge marks the World Conference against Racism, Racial Discrimination, Xenophobia, and Related Intolerance convened by the United Nations General Assembly from August 3 to September 7, 2001. The conference is taking place in the context of rising xenophobia and anti-refugee sentiment in the public discourse as well as increasingly restrictive laws in the North, accompanied by a powerful juggernaut called globalization. Migration is a key area where racism and discrimination continue to pervade all levels of policy and institutional practice. While refugee issues are expected to be part of the official conference agenda, we have proposed this special issue to further animate the debates and discussions surrounding racism and migration in the international context.

\section{"Race," Refugees, and Labour}

Traditionally, refugee issues were understood and studied from humanitarian perspectives. These studies focused on the plight of refugees all over the world and called for relief and humanitarian assistance. However, the current perspective on these issues goes beyond the conventional understanding. The term Complex Humanitarian Emergencies ( $\mathrm{CHE}$ ) indicates this shift in thinking. CHE describe the interconnected scenarios of refugee movements, forced migrations, civil wars, humanitarian assistance, and intervention.

In many important ways the issues and experiences of refugees and asylum seekers are qualitatively different from the issues of other migrants. In a liberal democratic context the problems of refugees and asylum seekers need to be addressed through internationally accepted and agreed mechanisms. Yet, these issues are generally subsumed under immigration laws. Historically, domestic immigration laws that govern the selection, importation, regulation, exploitation, and control of labour have been racist. This exemplifies the contradiction/dilemma that has been central to the nation-building process of white settler colonies. On the one hand states espouse the values of liberal democracy. However, on the other, the core of these states is colonial and racist because of their historical formation that was deeply rooted in racism and colonialism.

Immigration policy cannot be separated from labour and by logical extension also from the movement of global capital. Capitalism and globalization require cheap labour. Global capital moves without borders to where cheap labour is readily available. International instruments like the General Agreement on Trade in Services (gats), the North American Free Trade Agreement (NAFTA), and the Free Trade Agreement of the Americas (FTAA) facilitate and enhance the free movement of capital, while labour from the so-called Third World is locked within their national spaces and blocked from entering the West, stigmatized by a discourse concerning the "undesirables": illegal immigrants, aliens, economic migrants, and bogus refugees. In the process, economic inequalities are generated, which force people to migrate to places where they can sell their labour. Simultaneously, 
civil wars in various parts of the world are producing large numbers of refugees and displaced people that are in search of safe havens.

Realizing that migrations of this kind cannot be stopped, Western countries have instituted control mechanisms. Global migration control is the means by which the West regulates and manipulates the movement of people from the Third World and, depending on the need, can "select" highly skilled people as designer immigrants and refugees "suitable" for resettlement. While immigration policies have been explicitly linked to labour markets and demographics, refugee policies have not been linked explicitly to the needs and desires of the labour market of countries that traditionally depend on immigration for their labour supply. In the past decade even the Eu has moved towards accepting immigration as a major source for labour. This is an important shift in policy for the EU, not because the traditional contours of their "nation states" are being challenged by minorities, immigrants, and other "aliens," but because of the effect of this policy shift on Eu refugee and asylum policy.

In the Eu an extended lifespan, coupled with a significant decline in fertility, over the last four decades has resulted in a rapid transition to a much older population and a declining labour force. ${ }^{1}$ Consequently, in November 2000, the European Commission indicated that the EU should promote greater immigration. National governments within the EU are now beginning to adopt skillsbased immigrant recruitment programs. At the time of writing, the German Interior Minister has proposed new legislation that would enable Germany to receive a large number of skilled immigrants while tightening the rules for refugees and asylum seekers. ${ }^{2}$ There is a growing realization within the EU that refugees might provide an important source of cheap labour.

\section{Racism and Criminalizing Refugees and Migrants}

The us, Canada, Australia, and the eu have been cooperating in sharing information, pooling resources, and establishing intergovernmental organizations in the global control of migration of all sorts. For example, the International Center for Migration Policy and Development (ICMPD) was founded in 1993. The ICMPD came into being after intergovernmental consultations on asylum, refugee, and migration policies in Europe, Canada, the us, and Australia. There are at least thirty other networks set up by European states, with participation or contributions from the us, Canada, and Australia, to control glo- bal migration. ${ }^{3}$ The major task of these international mechanisms is to combat human smuggling and trafficking. In fact the year 2000 was declared as the year of the anti-trafficking plan by the eu, Group of 8, and the Organization for Security and Co-operation in Europe, which includes the us and Canada. Universal access to the rights of asylum and non-refoulement are fast disappearing from the agenda of powerful countries and multilateral organizations.

\section{Xeno-Racism}

Contributors to this volume analyze racism in migration policy in various international contexts and point to the emergence of xenophobia and a new form of racism. Links between xenophobia and racism are rarely made. The new form of racism is the combination of racism and xenophobia described by Sivanandan, director of the Institute of Race Relations in the UK, as xeno-racism. Xenoracism is racism in substance, but "xeno" in form. "It is a racism that is not just directed at those with darker skin, from the former colonial territories, but at the newer categories of the displaced, the dispossessed and the uprooted, who are beating at western Europe's door."' It is racism that is meted out to strangers, refugees, and poor immigrants. The papers in this volume also clearly point to the fact that economic viability and labour needs dominate the thinking of the emerging control regime.

In her paper "Nation Building and the Construction of Identity," Janet Reilly explains how the rise of xenophobia in post-apartheid South Africa can be understood in the context of state building and identity formation. Her paper is important for two reasons. First, her illustration of the inherent contradiction that exists between the aspirations of liberal democracy and the exclusivist nature of the identity formation - a process that always creates the others, aliens, foreigners, and visible minorities-is not only a mirror image of the Canadian, us, Australian, and other settler contexts, but it also signifies a major dilemma of liberal democracy. Second, the xenophobia in South Africa is mainly directed against fellow Africans. In this regard, the situation serves as a good example of xeno-racism. Reilly also highlights the importance of immigrant labour in the formation of South Africa.

In "Migration, Refugees, and Racism in South Africa," which will be published in the next issue of Refuge, Jeff Handmaker and Jennifer Parsley make the important connection between xenophobia and racism. As they point out, victims of xeno-racism are, "almost invariably, 
black people from African countries" whose "skins are darker, clothes more colourful, vaccination marks in different places, Africans unable to speak a local African language, and a host of other physical attributes not deemed 'South African' and therefore 'illegal."' Their article will include a report on the Durban Conference itself.

Anthony Richmond's paper focuses on refugees and racism in Canada. ${ }^{5}$ He provides us with an overview of Canadian racism and its impact on domestic refugee law and policy. Richmond situates his analysis of Canada's immigration policies and treatment of refugees in the global context and actions of other states and agencies. His argument that the "economically advanced countries of the world have welcomed temporary and permanent migrants including refugees when their own economies were in need of labour and skills, and imposed restrictions when economic and political conditions changed" is echoed in other papers of this volume as well. Richmond rightly concludes that a "non-exodus" approach to global migration from developing countries and the use of deterrents by Canada and other Western countries are forms of institutional racism, despite the numbers of racialized refugees actually admitted from the Third World.

The intersection of race and gender is the focus of Pittaway and Bartolomei's paper. They explore the notion of racism as a root cause of refugee generation and the gendered nature of the refugee experience. Using a case study of refugee policy in Australia, they illustrate the impact of discrimination on refugee women. Their paper clearly highlights the gap that exists between refugee policies and practices, and gender blindness in all aspects of policy.

Louise Humpage's article points out how the application of ostensibly "neutral" rules and universal standards produce systemic racism in the refugee resettlement context in New Zealand. Her critique that the liberal commitment to superficial pluralism does not take differences seriously evokes similar arguments in the discourse of official Canadian multiculturalism. ${ }^{6}$ This form of institutional discrimination, as she argues, "is, by definition, unconscious and unintended because of its embeddedness within structures, functions, and processes that are taken for granted." This is exactly what one would call the prevalence of "common sense" racism or "micro racism" as Anthony Richmond suggests—racism that has become part and parcel of our lives through centuries of internalization. Humpage asserts that a philoso- phy of economic rationalism dominates refugee policy, as it does immigration policy.

As the papers in this volume amply illustrate, the future of refugees and asylum seekers is indeed bleak. As fortress Europe tightly closes its door to refugees and asylum seekers, new policies and regulations are being formulated in Canada and the us to match the efficiency of Europe. In future, the reach of domestic refugee law and policy would not commence at the point of arrival in the West; rather, prevention of refugees from leaving their national spaces would be achieved by keeping them in open relief centres and camps for the displaced in the South. Refugees who still manage to flee would be stopped at the beginning point of their flight.

There is no doubt that delegates attending the World Conference against Racism will have a great deal of work to translate broad policy recommendations into concrete action in the fight against racism.

\section{Notes}

1. Federal Ministry of Labour, Health, and Social Affairs, A Society for All Ages: Employment, Health, Pensions and International Solidarity, background report of the European Union International Symposium (Vienna, 1998), 6.

2. International Herald Tribune, 4-5 August 2001, 4.

3. Liz Fekete, “The Emergence of Xeno-Racism," European Race Bulletin 37 (2001): 5 .

4. A. Sivanandan, quoted in Fekete, "The Emergence of XenoRacism."

5. There is a growing literature on this topic. For example, see A. Simmons, "Racism and Immigration Policy," Racism and Social Inequality in Canada, ed. V. Satzewitch (Toronto: Thompson Educational Publishing, 1998); and S. Aiken, "Racism and Canadian Refugee Policy," Refuge 18, no. 4 (1999): 2.

6. For an illuminating analysis and critique of Canadian multiculturalism and nationalism, see Himani Bannerji, Dark Side of the Nation: Essays on Multiculturalism, Nationalism, and Gender (Toronto: Canadian Scholars Press, 2000).

$R$. Cheran received his Ph.D. in sociology from York University. He is a research associate with York's Centre for Refugee Studies. 